„Śląskie Studia Polonistyczne” 2019, nr 1 (13) ISSN 2353-0928 (wersja elektroniczna)

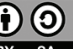

DOI 10.31261/SSP.2019.13.08

\section{Joanna Bednarek}

(iD https://orcid.org/0000-0003-3403-6629

\section{Mimetyzm, parler-femme i mówienie prawdy: kobiece wypowiedzi konfesyjne w perspektywie myśli Luce Irigaray}

Kobiecość, jak pokazuje Luce Irigaray w swoich wczesnych pracach, jest ontologicznym paradoksem. Ukrywająca się w szczelinach klasycznych tekstów, ich niespójnościach albo pod maską tyleż podejrzanych, co niezbędnych pojęć, takich jak materia pierwsza czy jouissance (IRIGARAY, 1985, s. 142, 162, 164, 168-169), nie jest ani „czymś”, ani „niczym”, wymyka się metafizyce substancji i stabilnemu sensowi. Ta konstatacja staje się dla filozofki punktem wyjścia radykalnego programu, tyleż filozoficznego, co politycznego i stylistycznego: rozsadzenia fallogocentrycznej ekonomii dopuszczającej istnienie tylko jednej, męskiej, płci, odtwarzającej się dzięki niewidocznej kobiecości, za pomocą strategii mimetyzmu, wywrotowego naśladowania kobiecości wszechobecnej w tekstach kultury (bo będącej ich konstytutywnym podłożem). „Początkowo istnieje być może tylko jedna »droga«, droga, którą w dziejach wytyczono tradycyjnie dla kobiecości - mimetyzm. Tę kobiecą rolę należy przyjąć na siebie świadomie i z rozmysłem, [...] po to, by »ujawnić« w trybie ludycznego powtórzenia to, co powinno pozostawać w ukryciu skrywaną i tłumioną możliwość odzyskania kobiecej sprawczej mocy w języku" (IRIGARAY, 2010, s. 63).

Filozofka sama dokonuje tego w swojej pierwszej książce: Speculum: de l'autre femme, będącej demontażem użytku, jaki robili z kobiecości wielcy filozofowie i prawodawcy Symbolicznego od Platona po Freuda. Powtarza i przepisuje ich wypowiedzi, które mają na celu opisanie, określenie kobiet, „kobiety” albo kategorii symbolicznie powiązanych z kobiecością, jak materia czy chora, i które w ten sposób określają kobietę jako inną, a kobiecość jako wykluczone, niewidoczne, ale zasadnicze podłoże filozofii. Proste krytykowanie tych wypowiedzi i stanowisk, dowodzenie, że kobiety nie są „w rzeczywistości” tym, czym każą im być filozofowie, nie jest bowiem - zdaniem Irigaray - skuteczne, gdyż oznacza godzenie się na fallogocentryczne kryteria racjonalności, niezdolność do ukazania mechanizmu odpowiedzialnego za wykluczenie i tym samym wymazywanie kobiecości oraz kobiet po raz kolejny. Dlatego od potępiania czy krytykowania wykluczającego charakteru konkretnych treści lepsza jest strategia rozmontowywania patriarchalnych tekstów od środka (KozEL, 1996). Jak 
podkreśla Katarzyna Szopa, „[p]oetyckość Irigariańskiej refleksji, a w szczególności »performatywny« ładunek jej poetyki, stanowi szczególny punkt oporu wobec mitotwórczego sposobu orzekania (o istocie rzeczy, prawdzie, płci) poprzez tworzenie alternatywnych systemów wyobrażeń, snucie odmiennych narracji i myślenie o tym, co »nie do pomyślenia«" (Szopa, 2018b, s. 26). Mówienie „o" kobietach i ich wykluczeniu jest znacznie mniej skuteczne niż mówienie z kobiecego (nie)miejsca, niemożliwej pozycji podmiotowej, które powołuje jednocześnie tę pozycję podmiotową do istnienia: „»mówienie-jako-kobieta«, bo tak należałoby tłumaczyć parler-femme" (SzOPA, 2018b, s. 143).

Program ten dowiódł swojej skuteczności już choćby przez to, że przekształcił oblicze filozofii feministycznej, dla której kobiecość jako różnica jest obecnie pojęciem podstawowym (SzOPA, 2018b, s. 97-151). Wydaje się, że to program idealny jako inspiracja dla teorii lub eksperymentalnego pisarstwa. Ale czy może przekształcić również inne rodzaje kobiecych/feministycznych wypowiedzi? Czy nie istnieje, ściślej mówiąc, przynajmniej jeden rodzaj kobiecej wypowiedzi, w przypadku którejlepiej nie destabilizować sensu - w przypadku której walczyć należy o coś dokładnie przeciwnego: o prawdę i wiarygodność?

Chodzi o wypowiedź, którą można by prowizorycznie nazwać świadectwem czy też wypowiedzią konfesyjną - to relacja o kobiecym doświadczeniu, na ogół traumatycznym, zgłaszająca roszczenie do prawdziwości - nie tyle czy nie tylko faktualnej („,x naprawdę się zdarzyło"), ile symbolicznej lub performatywnej („uwierzcie mi, uznajcie moją prawdę i mnie"). Pojęcie świadectwa (testimony) przejmuję od Leigh Gilmore, która w pracy Tainted Witness. Why We Doubt What Women Say About Their Lives (GILMORE, 2016) analizuje konwencje rządzące sieciami świadectwa (testimonial networks), decydujące o tym, jak trudno jest zyskać wiarygodność kobietom opowiadającym o swojej krzywdzie.

Świadectwo może przybrać postać zeznania w procesie sądowym, wypowiedzi konfesyjnej opublikowanej na portalu internetowym, autobiografii czy fikcji. Ten ostatni przypadek wydaje się wprawdzie kontrowersyjny - o ile zeznania czy autobiografie odnoszą się, choć w odmienny sposób niż świadectwo, do faktów, fikcja, nawet ta oparta na doświadczeniach autorki, z definicji miałaby się od tych faktów oddzielać. Sądzę, że ta klasyfikacja jest zbyt pochopna; fikcja nie wyraża bowiem realnego, czyli empirycznego doświadczenia (przynajmniej nie w taki sposób, jak choćby autobiografia), ale również odnosi się do doświadczenia kobiecego współkształtuje lub nawet tworzy konwencje, jakie wykorzystujemy, opowiada o nim czy demaskuje patriarchalne uwarunkowania pozwalające uznać daną kobietę i jej wypowiedź za wiary- 
godną, a inną zdyskwalifikować. Dlatego chcę fikcję potraktować jako jeszcze jeden teren, na którym toczą się feministyczne zmagania o prawdę.

Takie podejście do fikcji jest możliwe między innymi dlatego, że w walce o kobiecą wiarygodność nie chodzi tak naprawdę o fakty. Oczywiście trzeba je ustalić i jest to ważny aspekt walki o prawdę (najważniejszy w postępowaniu sądowym). Ale nawet kiedy nie ma żadnych wątpliwości co do faktów - kiedy wiemy, że miał miejsce gwałt czy molestowanie - wiele osób często swoje współczucie kieruje ku sprawcy, a ofiarę uważa za podejrzaną i niegodną ich empatii (por. MANne, 2018, s. 196-210) ${ }^{1}$. Dzieje się tak dlatego, że faktów nie można oddzielić od warunków dyskursywnych umożliwiających wypowiedzenie ich - tych faktów - w danym kontekście. „Prawda świadectwa związana jest nie z faktami, ale z władzą"2 (Gilmore, 2016, s. 15). W przypadku kobiecych świadectw czy wypowiedzi konfesyjnych warunki te określa patriarchalny układ sił, sprawiający, że kobieta wypowiadająca się publicznie znajduje się w niezwykle ryzykownym położeniu. Nie tylko jej słowa mogą zostać zakwestionowane - ona sama bardzo łatwo może stać się bohaterką skandalu i obiektem agresji. I słowa tej kobiety, i ona sama mogą bardzo łatwo zostać „splamione”. „W języku prawnym zarówno o niewiarygodnych świadkach, jak i o niewiarygodnych dowodach mówi się, że są splamione (tainted). Określenie to niesie z sobą skojarzenia zarówno z fizycznym zabrudzeniem, jak i z metafizyczną degradacją" (GILMORE, 2016, s. 19). Ofiara domagająca się sprawiedliwości często robi to w sposób „niewłaściwy” - zbyt agresywnie, zbyt płaczliwie albo przeciwnie, nie zdradzając odpowiednich emocji. Ona sama też jest niewłaściwa: prowadzi zbyt aktywne życie seksualne, jest zbyt pewna siebie, nie wygląda tak, jak powinna wyglądać osoba skrzywdzona...

Istnieją też inne przejawy tych niesprawiedliwych standardów oceny: nieproporcjonalna do rzeczywistych „przewin” agresja czy drwiny, które tak często ściągają na siebie celebrytki (DoYLE, 2016); mizoginia, z którą spotykają się, zamiast merytorycznej krytyki, polityczki (BEARD, 2018). Kobieta widoczna i przemawiająca w sferze publicznej to zawsze potencjalnie „kobieta upadła”. Jej słowa są dwuznaczne, a ona sama jakby z istoty kłamliwa i działająca z nieczystych pobudek (takich jak choćby zabieganie o uwagę). Bardzo trudno jest takiej kobiecie opowiedzieć „właściwą historię” (GIL-

1 Te podwójne standardy stosowane są, rzecz jasna, nie tylko w odniesieniu do kobiet, lecz także do wszystkich podmiotów „marginalnych” (czyli niebędących białymi bogatymi mężczyznami). Skupiam się na (cis)kobietach nie dlatego, że ich przypadek jest paradygmatyczny czy ważniejszy od innych, ale z pełną świadomością, że to tylko część całej historii o standardach publicznej obecności.

2 Jeżeli nie zaznaczono inaczej, fragmenty w przekładzie autorki artykułu. 
MORE, 2016, s. 9) - taką, która pozwoli opowiadającej zająć pozycję podmiotu wiarygodnego. Żeby tego dokonać, kobieta musi stać się „odpowiednią ofiarą" - godną uwagi i współczucia (jak postaram się pokazać, staje się nią niezmiernie rzadko, ale jest to możliwe).

Wydaje się, że to właśnie jest celem ruchu \#metoo: chodzi o ustawienie kobiet wreszcie na pozycji podmiotów, którym się wierzy, podmiotów wiarygodnych, prawdomównych, prawomocnych. Oznacza to oczywiście zmianę reguł gry, bo obecne reguły działają na korzyść mężczyzn, w tym sprawców przemocy. Niemniej walka o tę zmianę toczona jest środkami zakładającymi wytwarzanie efektu prawdy, który na pierwszy rzut oka wyklucza performatywną wieloznaczność mimetyzmu.

Czy znaczy to, że powinnyśmy próbować opowiadać „właściwą historię”? Próbować stać się „odpowiednimi ofiarami”? Co kryje się pod tymi pojęciami? Jakie byłyby konsekwencje osiągnięcia tego ambiwalentnego sukcesu?

Mówienie prawdy o sobie to, jak wiemy dzięki Michelowi FouCAULTOWI (2012, s. 300-305; 2018, s. 309, 321), wynalazek tyleż kluczowy dla podmiotowości, którą realizujemy jako uczestniczki nowoczesnej kultury zachodniej, co niebezpieczny. Żeby być podmiotem, trzeba mówić o sobie: ustanowić „pewien stosunek do samego siebie, tak stabilny, trwały, analityczny i szczegółowy, jak to tylko możliwe, stosunek, który da się ustanowić i który jest skuteczny tylko o tyle, o ile ze wszystkich stron podtrzymuje go dyskurs" (FouCAULT, 2012, s. 303); zyskujemy w ten sposób obietnicę obecności, ale i „obowiązek mówienia prawdy o samym sobie, na swój własny temat, i to w formie wyznania" (FoucAult, 2012, s. 303). Nasze słowa otwierają dla nas przestrzeń - w dyskursie i w życiu ale też przyszpilają nas w jednym miejscu, nadają nam tożsamość, która może stać się ograniczająca. Przede wszystkim jednak stawia się nas tu nieustannie przed niewidzialnym trybunałem, domagającym się wyznawania prawdy; choć rachunek sumienia, stanowiący niegdyś, jak dowodzi Foucault, instytucję, która powołała do życia wyznanie o sobie, należy w dużej mierze do przeszłości, nadal zmuszeni jesteśmy wyznawać swoją prawdę przed wieloma różnymi instancjami - zgwałcone kobiety muszą dowodzić przed sądem, że są „odpowiednimi ofiarami”; osoby transpłciowe muszą przekonywać lekarzy i sąd, że „naprawdę” są transpłciowe, by uzyskać zgodę na korektę płci (SERANo, 2007; Preciado, 2013; KosińSKA, 2015). Coming out - żądanie „uznania przez innych tego, kim jestem i za kogo się uważam" (BAsıuk, 2012, s. 61) - wciąż pozostaje ważnym aspektem polityki LGBT. Teoretyczki feministyczne i queer wielokrotnie zwracały uwagę na to, że z jednej strony wymogi te są często ograniczające, a czasem wręcz szkodliwe dla emancypacji nienormatywnych podmiotów (MCWHORTER, 1999; HUFFER, 2013). 
Z drugiej strony niekoniecznie wiąże się to z przymusem rezygnacji z tożsamości (kobiecej, lesbijskiej itd.) jako kategorii pozwalającej walczyć o uznanie.

Kobieca „opowieść o traumie” lub, szerzej, „opowieść o doświadczeniu” ujmowana jako podtyp „wyznania prawdy o sobie” ma jednak kilka cech charakterystycznych, które czynią z tej opowieści szczególnie niebezpieczne zjawisko. Unaoczniają to osobiste relacje będące ważną częścią walki z kulturą gwałtu: opowieści o przeżytej traumie mają wstrząsać odbiorcami, ukazywać im powszechność i normalizację przemocy seksualnej. Jednak, jak zauważa Amber A'Lee Frost, tego rodzaju wyznania są problematyczne pod co najmniej dwoma względami. Po pierwsze, są podatne na standaryzację i przekształcenie w „przemysł traumy”: portale internetowe, dla których najważniejsza jest klikalność, specjalizują się w masowym wytwarzaniu opowieści o gwałtach i molestowaniu: „rynek wynagradza osobiste opowieści uwagą - im bardziej są szokujące i szczegółowe, tym lepiej" (Frost, 2016). Po drugie (i ważniejsze), nawet te wyznania, które pojawiają się w kontekście wykluczającym takie instrumentalne podejście do nich - na przykład w antologiach (ClARK, Pino, 2016; GAY, 2018b) - wydają się przewidywać tylko jedną reakcję: „,wierzymy wam”. Zastrzeżenia do relacji ofiar często oznaczają podawanie w wątpliwość ich wiarygodności: przedstawianie ich jako niepoczytalnych, histerycznych, nadmiernie emocjonalnych, paranoicznych itd., a ich wypowiedzi jako niestosownych czy w złym guście. Akt apriorycznego zaufania, rezygnacji ze zgłaszania zastrzeżeń i z zadawania pytań ma być remedium na tę patriarchalną nierówność szans. Oznacza to jednak, że jedyne, co możemy i powinnyśmy zrobić w obliczu wyznania, to wierzyć: nie analizować dyskursu, broń Boże nie krytykować, nie myśleć - tylko wierzyć i odczuwać empatię. „Podczas tego aktu upamiętnienia mamy siedzieć, nie zadawać pytań i pogrążać się w bólu i współczuciu wywołanym jego przerażającą przyczyną" (Frost, 2016).

Podkreślam: kwestionowanie dyskursywnych uwarunkowań świadectwa nie oznacza występowania „przeciwko” ofiarom i ich potrzebie opowiedzenia o tym, co je spotkało, ani też negowania publicznej użyteczności świadectwa. Nie uważam także za słuszną konserwatywnej tezy, że polityka tożsamości z jej naciskiem na emocje i to, co osobiste, skaziła sferę publiczną i że kobiety oraz inne podmioty zmarginalizowane powinny, wkraczając do niej, zostawiać emocje w domu ${ }^{3}$. Upolitycznienie tego, co osobiste, wzbogaciło nasze

3 Deborah Nelson (2017) opisuje sposób tworzenia publicznej persony przez intelektualistki działające przed zmianami, jakie wywołała w amerykańskiej polityce i życiu kulturalnym Nowa Lewica, takie jak Hannah Arendt, Joan Didion czy Mary McCarthy, zwracając uwagę na ich „twardą”, „niesentymentalną” postawę, pozwalającą im uciec od stereotypowej kobiecości i zaistnieć w męskim środo- 
środki politycznej ekspresji; dyskurs na temat własnego doświadczenia, podobnie jak wszystkie rodzaje dyskursu, ulega jednak z czasem schematyzacji i przestaje przynosić zamierzone efekty. Dlatego nie powinien być wyłączony spod krytyki.

Autobiograficzne opowieści o traumie mogą więc być nieskuteczne. Jeszcze większe niebezpieczeństwo wiąże się jednak z tekstami fikcjonalnymi zapożyczającymi od nich czy też wykorzystującymi strategię świadectwa. Niezależnie od tego, czy teksty takie mają charakter autobiograficzny czy nie, nacisk zostaje w nich położony nie na pozatekstowe, rzeczywiste doświadczenie, niewidoczne w samym tekście, ale niejako z zewnątrz go legitymizujące, lecz na konwencje pozwalające ukazać traumę w języku. Dlatego problem schematyzacji i trudności z wywołaniem empatii u odbiorczyni musi przejawiać się w tych tekstach ze szczególną ostrością.

Nie ukrywam, że refleksje te narzuciły mi się przy okazji lektury konkretnej książki - Histeryczek Roxane GAY (2018a). Zbiór opowiadań autorki znanej z autobiograficznych esejów (GAY, 2014) i wspomnianej już antologii na temat kultury gwałtu (GAY, 2018b) przenosi w wymiar fikcji tematykę, której dotyczą też autobiograficzne świadectwa. W centrum każdego opowiadania znajduje się bohaterka (na ogół opowiadająca swoją historię w pierwszej osobie), która doświadczyła czegoś traumatycznego - gwałtu, molestowania, związku z przemocowym partnerem albo po prostu bycia kobietą w patriarchalnym społeczeństwie. Przemoc, której doznają kobiety, pozostaje głównym tematem tych tekstów - do tego stopnia, że każdy z nich jest właściwie ekspozycją stanu wiktymizacji i niczym więcej: w większości opowiadań nie pojawiają się żadne zwroty fabularne, nie rośnie napięcie, nie ma rozwiązań. Na początku poznajemy bohaterkę jako ofiarę; kilka stron później opuszczamy ją, cały czas jako ofiarę. Te historie powinny budzić empatię - i być może u innych czytelniczek budzą, ale ja czytałam książkę z narastającą irytacją i ze znudzeniem. Możliwe, że moja reakcja wynikała po części z odrazy do statusu ofiary i samych ofiar (której mogłam bezpiecznie dać upust, ponieważ były one postaciami fikcyjnymi) ofiara jest wszak bytem abiektalnym, nikt nie chce wchodzić z nią w zbyt bliski kontakt, żeby się tą abiektalnością nie zarazić... Sądzę jednak, że oprócz tego chodzi o coś więcej: te opowiadania polegają, podobnie jak autobiograficzne opowieści publikowane w antologiach i w internecie, na efekcie „wierz mi” - ale nie stoi za tymi tekstami prawdziwa cierpiąca osoba, której należy wierzyć i która legitymizuje swoją domniemaną obecnością tekst, być może słaby,

wisku. Kobiety te dokonały tego jednak za cenę odcinania się od feminizmu i pozostały postaciami wyjątkowymi, raczej potwierdzającymi stereotypy na temat własnej płci niż je kwestionującymi. 
schematyczny czy patetyczny ${ }^{4}$. Pozostaje fikcyjny teatr okrucieństwa, w którym bohaterki poddawane są wciąż tym samym katuszom - nie wiadomo do końca po co.

Badaczka starożytności Mary Beard zauważa, przy okazji analizy mechanizmów podtrzymujących, także dzisiaj, wykluczenie kobiet ze sfery publicznej, że w świecie antycznym istniały dwa wyjątki, w których dopuszczano zabieranie przez kobiety głosu. Pierwszy to mówienie w imieniu kobiet jako grupy interesu. Drugi - ważniejszy w niniejszym kontekście - to skarga, opowieść o cierpieniu, którego kobieta doświadczyła. „Kobiecie wolno się wypowiedzieć jako ofierze i męczennicy, zwykle w prologu do własnej śmierci" (BEARD, 2018, s. 25). Opowiadanie o traumie jako wyznanie często ma na celu zyskanie formy, kształtu - ale jest to kształt „cierpiącej”, jedyny zarezerwowany dla pojawiających się w sferze publicznej kobiet.

Filomela, Lukrecja czy, w nowożytności, Ofelia to postaci, których istnienie wyczerpuje się właśnie w takiej skardze; jako takie są przedmiotem fascynacji - o czym może świadczyć fakt, że często służą jako temat malarski. Zwłaszcza los Ofelii pokazuje, co dzieje się ze skrzywdzonymi kobietami, kiedy ich cierpienie spotyka się z zainteresowaniem. Choć jej postać można przetworzyć i wykorzystać w wywrotowych celach (Сzeczot, 2016, s. 33-46), w zwykłej, patriarchalnej perspektywie pozostaje Ofelia uosobieniem kobiecości tożsamej z szaleństwem, to zaś jest tożsame z naturą i ze śmiercią elementem „romantycznej nekroestetyki” (СzEсzot, 2016, s. 13-32). Nie chodzi tylko o to, że przekształcenie Ofelii w temat malarski odbiera jej słowa - już w dramacie Szekspira jej słowa w scenie szaleństwa nie są niczym więcej niż paradygmatycznym przykładem opowieści o kobiecej krzywdzie: „Te majaczenia mają więcej sensu niż normalna mowa [...]. Jest nauka w tym szaleństwie" (SHAKEsPEARE, 2013, s. 352) - problem nie w tym, że słowa Ofelii nie mają sensu, ale że mają go aż za wiele.

Wiktymizacja to zatem jedyny dostępny model przejawiania się kobiecości. Wydaje się, że taki właśnie wzorzec mówienia o traumie realizuje Gay. Jej bohaterki nie są ani szczególnie trudne (oryginalny tytuł książki to Difficult Women), ani szczególnie histeryczne - jedyne, czego chcą od swojego świata i od nas, czytelniczek, to móc opowiedzieć swoją historię. Akty mowy tych postaci nie naruszają w niczym zasad rządzących kobiecą wypowiedzią, ponieważ są tylko prywatnymi opowieściami o odtwarzaniu statusu ofiary - i same performa-

4 Na podstawie esejów z Bad Feminist można wnioskować, że przynajmniej jedno z opowiadań - końcowe Cudzy bogowie (GAY, 2018a, s. 241-262), w którym bohaterka pada ofiarą gwałtu zbiorowego - wykorzystuje doświadczenie samej autorki. Ilustruje to sposób krążenia wyznania w opisywanych przez Gilmore sieciach świadectwa przekraczającego granice między fikcją a autobiografią. Po raz kolejny można mi tutaj postawić zarzut „występowania przeciwko ofierze”. 
tywnie ten status odtwarzają. Opowieść o traumie przeistacza się w spektakl, który nie narusza w niczym patriarchalnego status quo.

Słowem: źle, kiedy społeczeństwo nie chce słuchać kobiecych opowieści o krzywdzie; ale wcale nie jest tak dobrze, jeśli chce ich słuchać. Dlatego właśnie pisane przez kobiety teksty o charakterze konfesyjnym (zarówno pamiętniki i biografie, jak i fikcja) mają tak dwuznaczny charakter. Z jednej strony od kobiet oczekuje się konfesyjności, a kultura popularna nieustannie zgłasza zapotrzebowanie na historie z życia wzięte; teksty poetek i pisarek (z Sylvią Plath i Virginią Woolf na czele) nieustannie przykrawane są tak, by pasowały do konfesyjnego wzorca. Z drugiej - „szczerość” tekstów kobiecych jest właśnie tą cechą, która uniemożliwia im zyskanie statusu „wielkiej literatury". Choć nie jest do końca prawdą, że kobiety piszą źle, bo nie mają nic do powiedzenia poza trywialnymi relacjami z własnego ograniczonego życia (jak pisała dawno temu Simone de BEAUVoIR - 2014, s. 789), nawet drastyczne prawdy o kondycji kobiet nie naruszają statusu ich dyskursu jako trywialnego. Pisana kobiecość to zatem (podobnie jak kobiecość przeżywana) double bind: jest zarazem zbyt szczera i zbyt kłamliwa, przywiązana do swojej istoty i tej istoty pozbawiona, zawsze podatna na przekształcenie w spektakl ${ }^{5}$. Jak przerwać ten zaklęty krąg trywializacji i sensacjonalizacji, pomijania kobiecych słów i słuchania ich z niewłaściwych powodów? Innymi słowy: jak przełożyć strategię mimetyzmu Irigaray na kwestię polityki mówienia o traumie/niesprawiedliwości? Dwóch przykładów dostarczą fikcja i (zapośredniczone przez internet) życie.

Bohaterka powieści Siri Hustvedt Świat $w$ płomieniach, niedoceniona artystka Harriet Burden, decyduje się wypuścić w świat trzy swoje projekty pod męskimi nazwiskami. Na pozór nie chodzi tu w ogóle o świadectwo: sztuka Harriet nie jest konfesyjna, co więcej, dotyczy w dużej mierze zwodniczości doświadczenia i pamięci, którym zawsze towarzyszy konfabulacja. Całe przedsięwzięcie ma na celu zdemaskowanie mechanizmów wykluczania kobiet przez świat sztuki. Jednak nie tylko: Harriet faktycznie chce zyskać uznanie jako artystka, jako człowiek i jako kobieta (te trzy rzeczy są nierozłączne) - ale walcząc o nie, nie wybiera bezpośredniej wypowiedzi konfesyjnej czy metadyskursu, lecz system masek. Wykluczenie i walka z nim zostają odegrane, nie opisane.

To strategia bardzo podobna do tej zastosowanej przez Irigaray w Speculum. Podobna, ale nie taka sama: o ile filozofka cytuje wypowiedzi sławnych mężczyzn na temat kobiety, kobiecości i materii,

5 Dlatego być może, jak pisze Katarzyna Szopa, także sama Irigaray unika autobiograficzności i pisze w sposób „niepersonalny”; filozofka unika w ten sposób redukcji jej myśli do „partykularnego” doświadczenia - choć ślady tego doświadczenia są w tej myśli silnie obecne (Szopa, 2018a). 
przemieszczając je, wytwarzając w nich luki i nasycając te luki wywrotową kobiecością, fikcyjna artystka opatruje kobiecą treść dzieł sztuki symboliczną męską sygnaturą. W obu przypadkach można jednak mówić o odwrotności - a może o przewrotnym wykorzystaniu? - mechanizmu opisanego rzezJoan Riviere w eseju Womanliness as a Masquerade [Kobiecośćjako maskarada]. Psychoanalityczka opisuje w nim przypadek (niektórzy spekulują, że autobiograficzny; zob. BUTLER, 2008, s. 124) intelektualistki ukrywającej się za maską ostentacyjnej kobiecości po to, by uniknąć odwetu ze strony mężczyzn, których miejsce kobieta chce zająć (RIVIERE, 1991, s. 94). Choć sama Riviere zakłada ciągłość między płcią, seksualnością a władzą (BUTLER, 2008, s. 124-127), dochodzi do wniosku, że nie da się oddzielić „prawdziwej” kobiecości od jej maski (RIvIERE, 1991, s. 94), które to spostrzeżenie staje się dla Butler jednym ze źródeł teorii performatywności płci.

Zarówno Irigaray, jak i Harriet Burden wykorzystują mimikrę męskości do ukazania sposobów, w jakie kobiecość zostaje wykluczona z dyskursów filozofii i sztuki. Obie chowają się za męskością nie po to, by być bezpieczne, ale by zdemaskować mechanizmy władzy. Irigaray „mówi” Plotynem i Freudem; Burden tworzy dzieła zainspirowane konkretnymi sytuacjami współpracy z mężczyzna mi artystami. „Każda z artystycznych masek stała się dla Burden "postacią imaginatywną «, wizualnym rozwinięciem »hermafrodytycznej jaźni «, o której nie można powiedzieć, że należy do niej albo do maski, lecz do »mieszanej rzeczywistości « powstałej miedzy nimi" (HustvedT, 2017, s. 6). Cudzysłowy ostrokątne obecne w tym cytacie ukazują, że kwestia masek i mimetyzmu zostaje rozegrana również na poziomie formy powieści, wielogłosowej, palimpsestowej, pełnej fikcyjnych interpretacji dzieł Burden i interpretacji interpretacji.

To ryzykowny projekt. O ile Irigaray udało się, mimo licznych przeszkód, go zrealizować, Harriet częściowo ponosi porażkę: jeden z mężczyzn zawłaszcza pracę bohaterki i zaprzecza, jakoby współpraca w ogóle miała miejsce. Mimetyzm nie jest bezpieczną strategią - ale czy jakakolwiek strategia walki z patriarchatem, włączając „kulturalną debatę", jest bezpieczna?

Kontrowersyjność tej strategii, zatarta w przypadku dzieła Irigaray, które zyskało, przynajmniej w obrębie teorii feministycznej, szacowność kanonu, została ukazana w bardzo świeżym przypadku aktywizmu internetowego. Krytyczka i aktywistka Maja Staśko zaczęła, po otrzymaniu od pewnego mężczyzny gróźb i wszczęciu postępowania $\mathrm{w}$ tej sprawie, a także spotkaniu się z agresją internautów kwestionujących prawo kobiety do nazywania się osobą skrzywdzoną, publikować na swoim Facebooku selfie podpisane: „Jak powinna wyglądać skrzywdzona osoba, żebyś jej uwierzył? Może imprezować? Może być beztroska? Może wracać sama po zmroku 
do domu? Może uczestniczyć w kulturze? Może mieć fajne życie? Może ci nie przedstawić całej historii przemocy, której doświadczyła w życiu?" (Facebook, Maja Staśko, 27.10. 2018, 28.10.2018, 28.10. 2018, 28.10.2018, 31.10.2018, 4.11.2018). Niezależnie od tego, jak potoczy się dalej ta historia, owa taktyka zasługuje na uwagę.

Patriarchalna opinia publiczna stawia osobom skrzywdzonym dwa powiązane wymogi: „musisz być nieszczęśliwa, inaczej nie jesteś prawdziwą ofiarą” i „powiedz prawdę o swoim cierpieniu, wzbudź naszą empatię, zapewnij nam spektakl”. Spełnienie ich nie zagwarantuje oczywiście, że spotkamy się z uznaniem tego cierpienia - równie dobrze możemy zostać uznane za płaczliwe i histeryczne. Dlatego być może lepiej w ogóle zrezygnować z walki o wiarygodność?

Maja Staśko przybiera maskę skrajnie „niewiarygodnej” ofiary, a ściślej, mówi z niemożliwego miejsca. Jednocześnie rości sobie prawo do statusu ofiary i nie zapewnia pokazu cierpienia, który powinien temu roszczeniu towarzyszyć; jakby mówiła: ,jestem ofiarą, ale nie jestem nieszczęśliwa; odmawiam pokazywania wam mojego cierpienia, jeśli chcecie spektaklu mojej traumy, to się rozczarujecie”. Nie gwarantuje to sukcesu, bo oznacza wystawienie się na zarzuty oszustwa i poszukiwania uwagi za wszelką cenę (ale, jak widziałyśmy, właściwie każda próba opowiedzenia o doświadczonej niesprawiedliwości oznacza narażenie się na takie ataki), stanowi jednak próbę odmowy udziału w „grze o wiarygodność”. W odróżnieniu od zwykłej sytuacji, która polega raczej na tym, że autentyczne cierpienie nie jest przez odbiorców odbierane jako autentyczne i w najlepszym razie traktowane jako spektakl, mamy do czynienia z „pustym” roszczeniem do wiarygodności, któremu towarzyszą obrazy osoby skrzywdzonej jako silnej i beztroskiej. Spójność przekazu zostaje zakłócona, co otwiera przestrzeń do dyskusji na temat naszych standardów prawdomówności i wiarygodności.

Świadectwo poddaje się zatem dekonstrukcji; więcej, ta dekonstrukcja może być jedynym sposobem na uniknięcie wyczerpującej walki o wiarygodność, próby sprostania sprzecznym wymogom, skazującej nas z konieczności na porażkę. Choć w pewnych sytuacjach rzeczywiście chodzi głównie o ustalenie, co się stało i kto mówi prawdę, ten wymiar walk o uznanie krzywdy stanowi tylko ich niewielką część. Po uwzględnieniu wszystkich mechanizmów działających na rzecz odbierania słowom kobiet wiarygodności i autorytetu nawet wtedy, gdy jest oczywiste, że mówią one prawdę, okazuje się jak, mam nadzieję, udało mi się choć w niewielkim stopniu pokazać - że najskuteczniejszą strategią walki o odzyskanie własnych słów może być zmierzenie się z żywiołem kłamliwości, niewiarygodności, nieautentyczności oraz próba przejęcia go i wykorzystania do własnych celów. 


\section{Bibliografia}

BAsıuk Tomasz, 2012: Coming out a queer: kontekst amerykański, kontekst polski. W: Strategie queer. Od teorii do praktyki. Red. Monika KŁosowSKA, Mariusz Drozdowski, Agata StAsińska. Warszawa: Difin.

BeARD Mary, 2018: Kobiety i władza: manifest. Przeł. Ewa Hornowska. Poznań: Dom Wydawniczy Rebis.

Beauvoir Simone de, 2014: Druga płeć. Przeł. Gabriela Mycielska, Maria LeśniewsKa. Wstęp do pol. wyd. Magdalena ŚrodA. Wyd. 3. Warszawa: Czarna Owca.

Butler Judith, 2008: Uwikłani w płeć. Feminizm i polityka tożsamości. Przeł. Karolina Krasuska. Wstęp Olga Tokarczuk. Warszawa: Wydawnictwo Krytyki Politycznej.

Clark Annie E., Pino Andrea L., 2016: We Believe You: Survivors of Campus Sexual Assault Speak Out. New York: Henry Holt and Company.

Czeczot Katarzyna, 2016: Ofelizm: romantyczne zawłaszczenia, feministyczne interwencje. Warszawa: Instytut Badań Literackich PAN. Wydawnictwo.

Doyle Sady, 2016: Trainwreck: The Women We Love to Hate, Mock, and Fear... and Why. New York: Melville House Publishing.

Foucault Michel, 2012: Hermeneutyka podmiotu. Przeł. Michał Herer. Warszawa: Wydawnictwo Naukowe PWN.

Foucault Michel, 2018: Rządzenie żywymi. Przeł. Michał Herer. Warszawa: Wydawnictwo Naukowe PWN.

Frost Amber A'Lee, 2016: Confession Booth. The Trouble with the Trauma Industry. „The Baffler”, no. 1. [Online:] https://thebaffler.com/salvos/ confession-booth-frost [10.11.2018].

GAY Roxane, 2014: Bad Feminist. New York: Harper Perennial.

Gay Roxane, 2018a: Histeryczki. Przeł. Dorota Konowrocka-SAwa. Warszawa: Wydawnictwo Poradnia K.

GAY Roxane, 2018b: Not That Bad:Dispatches from Rape Culture. New York: Harper Perennial.

GILmore Leigh, 2016: Tainted Witness. Why We Doubt What Women Say About Their Lives. New York: Columbia University Press.

HUfFER Lynne, 2013: Are the Lips a Grave? New York: Columbia University Press.

HuStVedt Siri, 2017: Świat w płomieniach. Przeł. Jerzy Koz£owski. Warszawa: W.A.B.

IRIGARAY Luce, 1985: Speculum of the Other Woman. Trans. Gillian C. GILL. Ithaca, N.Y.: Cornell University Press.

IrIGARAY Luce, 2010: Ta płeć (jednq) płcią niebędąca. Przeł. Sławomir KRóLAK. Kraków: Wydawnictwo Uniwersytetu Jagiellońskiego.

Kosıńska Kinga, 2015: Brudny róż. Zapiski z życia, którego nie było. Warszawa: Wydawnictwo Nisza.

Kozel Susan, 1996: The Diabolical Strategy of Mimesis: Luce Irigaray's Reading of Maurice Merleau-Ponty. „Hypatia”, vol. 11, no. 3. 
Manne Kate, 2018: Down Girl. The Logic of Misogyny. New York: Oxford University Press.

McWhorter Ladelle, 1999: Bodies and Pleasures. Foucault and the Politics of Sexual Normalization. Bloomington: Indiana University Press.

Nelson Deborah, 2017: Tough Enough. Arbus, Arendt, Didion, McCarthy, Sontag, Weil. Chicago: University of Chicago Press.

Preciado Paul, 2013: Testo Junkie. Sex, Drugs, and Biopolitics in the Pharmacopornographic Era. New York: The Feminist Press.

RIVIERE Joan, 1991: Womanliness as a Masquerade. In: The Inner World and Joan Riviere: Collected Papers, 1920-1958. Ed. Athol Hughes. Foreword by Hanna SEGAL. London-New York: Routledge.

SERANO Julia, 2007: Whipping Girl. A Transsexual Woman on Sexism and the Scapegoating of Femininity. Boston: Seal Press.

SHAKeSPEARE William, 2013: Tragediei kroniki. Przeł. Stanisław BARAŃCZAK. Kraków: Znak.

Szopa Katarzyna, 2018a: Filozofia feministyczna i autobiografia: wokót myśli Luce Irigaray. „Autobiografia”, nr 1(10).

Szopa Katarzyna, 2018b: Poetyka rozkwitania. Różnica płciowa w filozofii Luce Irigaray. Warszawa: Instytut Badań Literackich PAN.

\section{Joanna Bednarek}

Mimeticism, Parler-Femme, and Truth Telling:

Female Confessional Utterances in the Perspective of Luce Irigaray's Thought

Summary: This article's aim is to show, as exemplified by fiction and activism, that the concept of mimeticism appearing in Luce lrigaray's early works may prove to become instrumental in overcoming difficulties associated with giving witness or uttering a confession. Though ostensibly they are uttered to "tell the truth," or to produce the authenticity effect, thanks to lrigaray's optics, we may gauge their efficacy under present circumstances by deconstructing their alleged veracity and the credibility of the witness-giver.

Keywords: Luce Irigaray, witness, confessionality, truth telling

Joanna Bednarek

Mimétisme, parler-femme et le discours de vérité : les énoncés féminins de confession dans la conception de Luce Irigaray

Résumé : Le but de l'article est de montrer sur l'exemple de la fiction littéraire et de l'activisme que la conception du mimétisme de premiers ouvrages de Luce Irigaray peut s'avérer utile pour convaincre les difficultés accompagnant le témoignage ou bien l'énoncé de confession. L'optique d'rigaray permet de remarquer que la condition de l'efficacité du témoignage dans les conditions actuelles peut être une déconstruction de sa véracité et de la crédibilité de celle qui les apporte malgré qu'au premier regard il semble que le but de cet énoncé est un discours de la vérité. Mots clés : Luce lrigaray, témoignage, confession, discours de vérité 